\section{Observed Frequency and Characteristics of Hearing Loss in Osteogenesis Imperfecta}

\author{
SOFIA WAISSBLUTH ${ }^{1}$, KARINA LIRA ${ }^{1}$, KARINA ARACENA $^{1,2, a}$, \\ JAVIER OYARZUN ${ }^{1, a}$, MATIAS WILLSON ${ }^{1}$, CRISTIÁN SEILTGENS $^{3}$
}

\section{ABSTRACT}

Background: Osteogenesis imperfecta (OI) is a rare group of genetic disorders affecting connective tissue, with consequent bone fragility, frequent fractures and skeletal deformity. Depending on the type, patients can have blue sclera, dentinogenesis imperfecta, and hearing loss. Aim: To determine the frequency, type and audiometric characteristics of hearing loss in a group of patients with OI. Material and Methods: A prospective cohort study was completed. A clinical and diagnostic hearing evaluation with tympanometry, acoustic stapedial reflex, pure-tone and speech audiometry were performed. Results: Thirty patients completed the study; mean age of 22 years (range 6-63 years). Sixty seven percent had a type I OI. Overall, nine (30\%) patients had hearing loss (15/60 ears). Of these, six had bilateral hearing loss. Of the 15 affected ears, six showed conductive hearing loss, five sensorineural hearing loss, and four mixed hearing loss. Patients with hearing loss were older than patients with normal hearing. Only one pediatric patient developed hearing loss. Of the ears without hearing loss, $13 \%$ did not have an acoustic stapedial reflex. Conclusions: In this group of patients with OI, 30\% had hearing loss and among those ears with normal hearing, $13 \%$ did not have an acoustic stapedial reflex. Patients with OI should be monitored for hearing loss.

(Rev Med Chile 2020; 148: 1780-1786)

Key words: Hearing Loss; Osteogenesis Imperfecta; Otosclerosis; Reflex, Acoustic.

\section{Frecuencia y características de hipoacusia en osteogénesis imperfecta}

Antecedentes: La osteogénesis imperfecta (OI) es un grupo raro de trastornos genéticos que afectan al tejido conectivo, con la consiguiente fragilidad ósea, fracturas frecuentes y deformidad esquelética. Según el tipo, los pacientes pueden presentar escleras azules, dentinogénesis imperfecta e hipoacusia. $\mathbf{O b}$ jetivos: Determinar la frecuencia, tipo y características audiométricas de la hipoacusia en un grupo de pacientes con OI. Material y Métodos: Se completó un estudio de cohorte prospectivo. Se realizó una evaluación clínica, y de la audición con timpanometría, reflejo estapedial, audiometría tonal y logoaudiometría. Resultados: Treinta pacientes completaron el estudio; edad media de 22 años (rango 6-63 años). El 67\% tenía una OI tipo I. Nueve pacientes (30\%) tuvieron hipoacusia (15/60 oídos). De estos, seis tenían hipoacusia bilateral. De

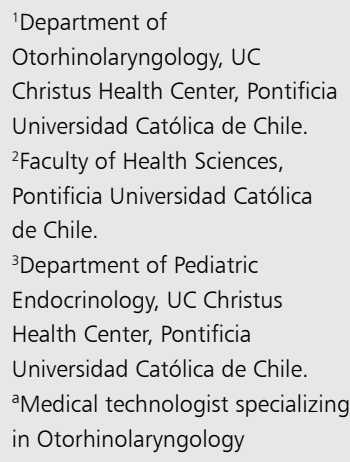

Recibido el 24 de mayo de 2020, aceptado el 17 de diciembre de 2020

Correspondence:

Dr. Sofia Waissbluth

Department of

Otorhinolaryngology, UC

Christus Health Center, Pontificia Universidad Católica de Chile, Marcoleta 352. Santiago, Chile. sofia.waissbluth@gmail.com 
los 15 oídos afectados, seis tenían hipoacusia de conducción, cinco hipoacusia neurosensorial y cuatro hipoacusia mixta. Los pacientes con hipoacusia eran mayores que los pacientes con audición conservada. Sólo un paciente pediátrico desarrolló hipoacusia. De los oídos sin hipoacusia, el 13\% tenía un reflejo estapedial ausente. Conclusiones: En este grupo de pacientes con OI, el 30\% tenía hipoacusia. Además, el 13\% de los oídos con audición normal no tenía reflejo acústico estapedial. Los pacientes con OI deben ser monitoreados para detectar hipoacusia.

Palabras clave: Hipoacusia; Osteogenesis imperfecta; Otosclerosis; Reflejo acústico.

$\mathrm{O}$ steogenesis imperfecta $(\mathrm{OI})$ is a genetically heterogeneous connective tissue disorder. It is a rare disease, with an estimated prevalence of $1: 10,000$ and to date, there is no cure. These patients have increased bone fragility and low bone mass with consequent frequent fractures and bone deformities. They may have scoliosis, short stature, ligamentous laxity, and also many extra-skeletal manifestations ${ }^{1}$. Because of its heterogenous clinical presentation, a classification of four different types of OI (I-IV) was initially created by Sillence et al in 1979. However, the classification has evolved substantially since then as genetic testing has allowed the identification of new subtypes, with a total of 19 genetic subtypes described up to now ${ }^{1-3}$.

Most cases (85-90\%) are due to mutations of the genes encoding type I collagen (COL1A1, COL1A2), which is the main component of the extracellular matrix found in bone and skin. All four initial types of OI involves either of these genes ${ }^{1}$. With advancements in sequencing, non-collagen genes have been identified to be involved in OI including genes encoding for proteins that are involved in collagen processing, bone cell differentiation, and mineralization ${ }^{2,4}$.

It has been described that patients with OI can develop hearing loss (HL). It is believed that $\mathrm{HL}$ is a result of a variety of abnormalities, which seem to be different depending on the type of OI. Temporal bones of OI patients show delayed patterns of ossification, otosclerotic lesions, microfractures of the ossicles, stapes footplate fixation and/or obliteration of the round window ${ }^{5-8}$. As a result, patients can develop conductive (CHL), sensorineural (SNHL) or mixed $\mathrm{HL}^{5}$.

Because it is a rare disease, and varies clinically based on the subtype, the prevalence of HL in OI patients has not been clearly described, varying between 2 and $94 \% \%^{5}$. Most case-series on this subject originate from North America, Europe and Australia ${ }^{5,9,10}$. To the best of our knowledge, there are only two articles reporting HL in OI patients from South America; a case series from Brazil, and a pediatric case-series from Venezuela ${ }^{11,12}$.

The objective of this study was to determine the frequency of $\mathrm{HL}$ in patients suffering from OI in Chile. The main outcome was the presence of $\mathrm{HL}$, and the secondary outcomes were to describe the types of HL and evaluate the presence of the stapedial reflex.

\section{Materials y Methods}

\section{Ethics approval}

Ethics approval for this study was obtained from the research ethics committee at the Pontificia Universidad Católica de Chile. All procedures performed were in accordance with the ethical standards of the institutional research committee, and with the Helsinki Declaration. Written informed consent was obtained from all patients involved in the study. For children, an informed permission of the parents with the assent of the child was recorded.

\section{Patient selection}

All patients with a diagnosis of OI under medical follow-up at the pediatric endocrinology department at the Pontificia Universidad Católica were contacted and invited to participate in this study. We identified 91 patients: 15 refused to participate, 43 could not reached, and 15 were interested but could not participate as they live in other regions of the country, and because of their disability, could not travel safely to Santiago. We, therefore, included 18 patients. Because of poor 
accrual, we contacted the OI Foundation of Chile (FOICH: Fundación de Osteogénesis Imperfecta Chile), and invited their members to participate, an additional 12 participants we added with a final number of participants for the study totalling $\mathrm{n}=30$. Demographics, family history of OI, treatments for OI, and HL risk factors were recorded.

\section{Audiological evaluation}

Patients recruited in this study had a complete clinical otolaryngology examination. A tympanometry, acoustic stapedial reflex measurement, pure-tone audiometry and speech discrimination were then performed. Pure-tone air conduction thresholds and bone conduction thresholds were obtained for the frequencies $128,256,512$, 1024, 2048, 3000, 4096, 6000 and 8196 Hz. Any frequency with a threshold of $20 \mathrm{~dB}$ or greater was considered as HL. HL at $1024 \mathrm{~Hz}$ or lower is considered low frequency HL, while HL at 2048 or greater is considered high frequency HL. The

Table 1. Patient demographics

\begin{tabular}{|ll|}
\hline Total & $\mathrm{n}=30(\%)$ \\
Gender & \\
Male & $20(66.7 \%)$ \\
Female & $10(33.3 \%)$ \\
Age: & \\
Mean \pm st dev. & $22 \pm 12.7$ yrs \\
Median & $20 \mathrm{yrs}$ \\
Range & $6-63 \mathrm{yrs}$ \\
& \\
$0-10$ yrs & $6(20 \%)$ \\
$11-20$ yrs & $9(30 \%)$ \\
$21-30$ yrs & $6(20 \%)$ \\
$31-40$ yrs & $6(20 \%)$ \\
$41-50$ yrs & $1(3 \%)$ \\
$51-60$ yrs & 0 \\
61 yrs and over & $1(3 \%)$ \\
& \\
Pediatric patients (<18 yrs) & $12(40 \%)$ \\
OI type & \\
I & $20(66.7 \%)$ \\
II & 0 \\
III & $6(20 \%)$ \\
IV & $4(13.3 \%)$ \\
Mamily history & \\
Paternal line & $7(23 \%)$ \\
Neonatal hearing screening & $9(30 \%)$ \\
\hline
\end{tabular}

severity of HL was defined as mild when the average shift for the frequencies with a threshold of $20 \mathrm{~dB}$ or greater was $20-40 \mathrm{~dB}$, moderate if $41-60$ $\mathrm{dB}$, and severe if over $61 \mathrm{~dB}$. The Mann-Whitney $\mathrm{U}$ test was used to calculate differences between patients with and without HL.

\section{Results}

\section{Demographics}

Patient characteristics are described in Table 1. The median was 20 years, and $40 \%$ were less than 18 years old. Most of the patients evaluated were from the Santiago Metropolitan region (Figure 1). Only seven patients refer neonatal hearing

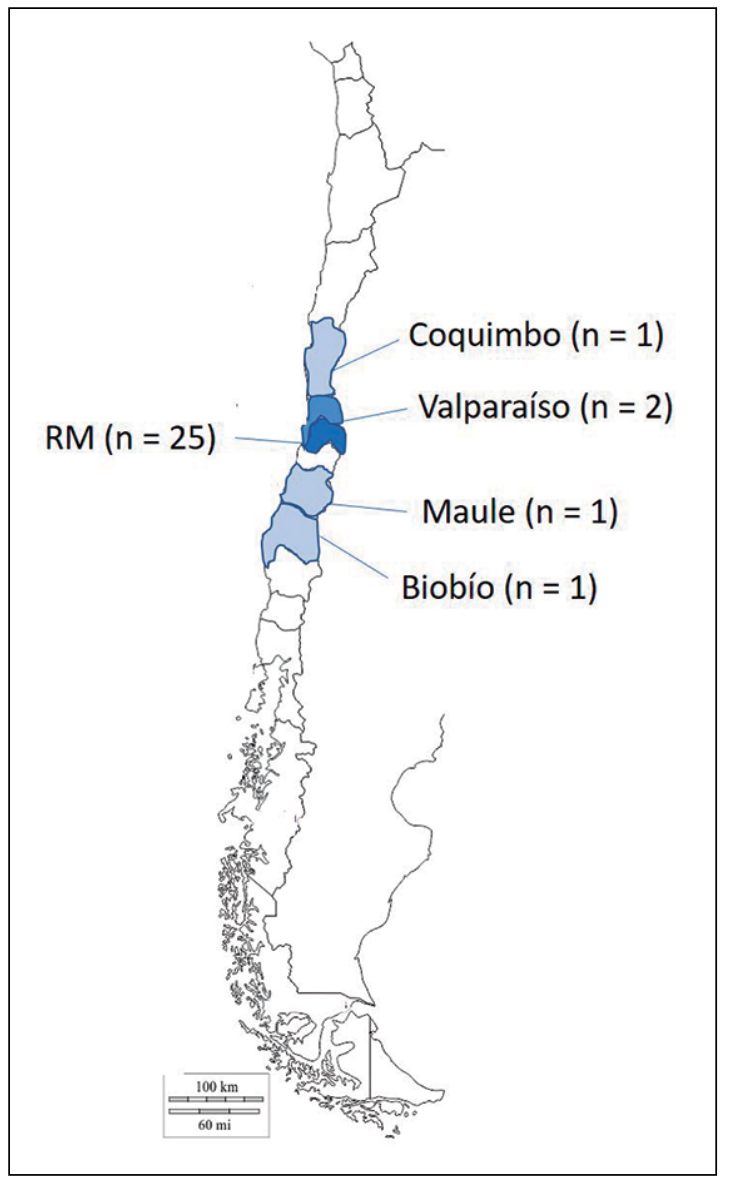

Figure 1. National distribution of the patients recruited in the study. Most of the patients were from the Santiago Metropolitan region. However, cases were also seen from neighbouring regions. 
screening, and for all, results were normal. As for HL risk factors, no patients refer temporal bone fractures, noise exposure, or use of ototoxic medications; 4 refer neonatal hyperbilirubinemia (no treatment required), 5 were low birthweight (only $1<1500 \mathrm{~g}$ ), 1 had a history of grommets for otitis media with effusion (resolved), and 1 had a history of an ear surgery (a unilateral atticotomy with normal hearing following surgery).

\section{Tympanometry and acoustic stapedial reflex measurement}

Normal tympanograms were observed for $88.3 \%$ of the ears $(n=53 / 60)$. Abnormalities were seen in: 3 ears with Ad curves, 2 ears with As curves, 1 ear with A double peak, and 1 ear with a $\mathrm{C}$ curve. The acoustic stapedial reflex was absent in $28.3 \%$ of ears $(n=17 / 60)$.

\section{Pure-tone audiometry}

Overall, $30 \%$ of patients had HL $(n=9 / 30$;
15/60 ears). Of these 9 patients, 6 has bilateral HL. Of the 15 affected ears, 6 showed CHL, 5 showed SNHL, and 4 showed mixed HL. An example of unilateral CHL can be seen in Figure 2. HL severity was as follows: mild in 6 ears, moderate in 5 ears, and 4 ears were severe. Most presented HL through all of the frequencies $(66.7 \%=$ $10 / 15$ ears) while 2 ears were affected in the low frequencies only, and 3 were affected in the high frequencies only. Of the ears without HL, 13.3\% did not have an acoustic reflex $(n=6 / 45)$. Also, HL was most common in type I OI (66.7\%). In the adult group $(n=18 / 30)$, patients with HL were, on average, twelve years older than patients with normal hearing. HL was not more frequent in the female gender. When comparing adults with and without HL, statistically significant hearing threshold shifts were seen for all of the tested frequencies (Table 2). In the pediatric group, only one patient presented a mild SNHL in the high frequencies $(n=1 / 12)$.

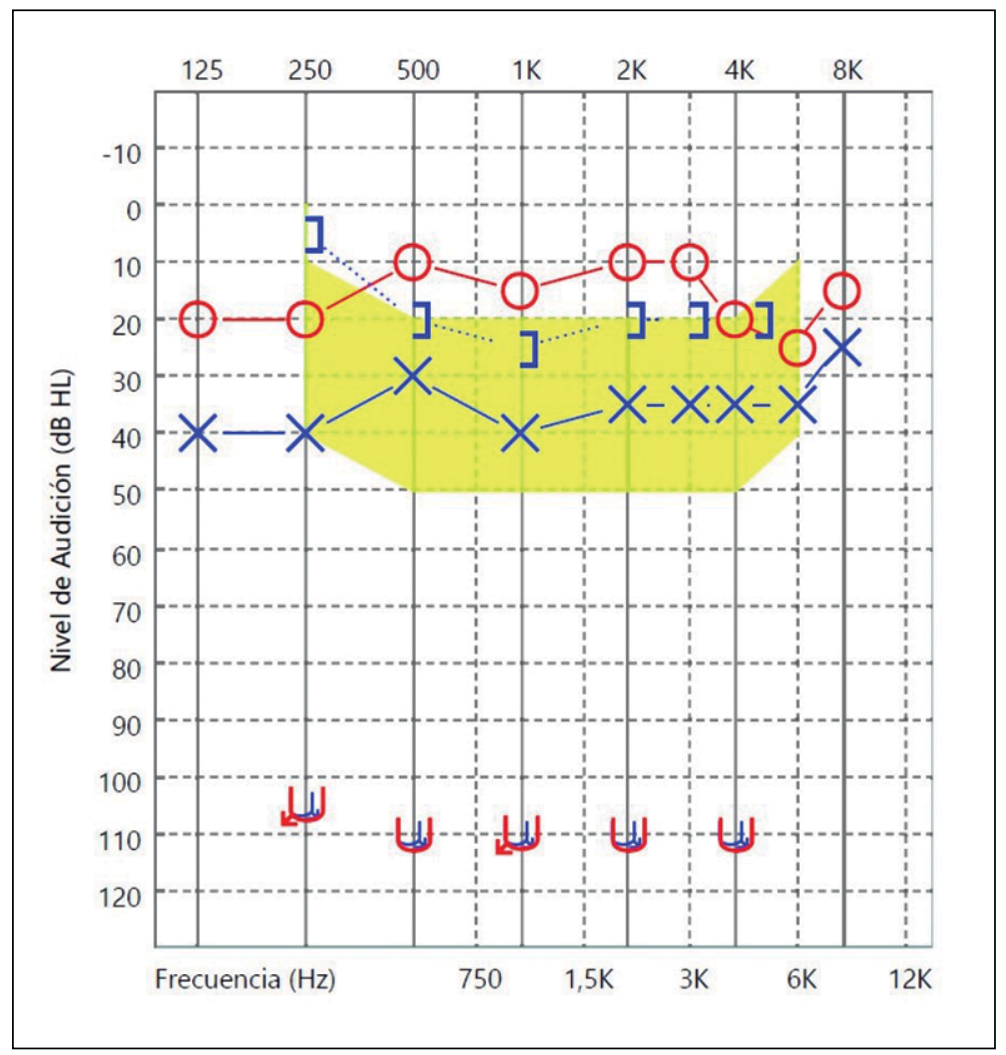

Figure 2. Example of hearing loss on a pure-tone audiogram. This audiogram shows a conductive hearing loss for the left ear for a 28-yeard old female patient. Red circles depict normal hearing thresholds for the right ear, while the blue " $X$ " (air conduction) and "]" (bone conduction) depict a conductive hearing loss for the left ear. An air-bone gap can be seen for the left ear for the frequencies of $250 \mathrm{~Hz}$ to $4 \mathrm{kHz}$. 
Table 2. Audiological findings for adults ( $\geq 18$ years) with osteogenesis imperfecta

\begin{tabular}{|c|c|c|c|}
\hline & Without hearing loss & With hearing loss & $\begin{array}{c}\text { Mann-Whitney U test } \\
\text { (p-value) }\end{array}$ \\
\hline Age $^{a}$ & $24.2 \pm 6.2 \mathrm{yrs}$ & $36.2 \pm 11.9 \mathrm{yrs}$ & $0.0014^{*}$ \\
\hline Gender (female) & $\mathrm{n}=7 / 10$ & $n=5 / 8$ & 0.8258 \\
\hline \multicolumn{4}{|c|}{ Average hearing threshold $(\mathrm{dB})$} \\
\hline $128 \mathrm{~Hz}$ & $13.8 \pm 4.6$ & $42.8 \pm 21.4$ & $<0.0001^{*}$ \\
\hline $256 \mathrm{~Hz}$ & $13.0 \pm 4.1$ & $46.0 \pm 25.9$ & $<0.0001^{*}$ \\
\hline $512 \mathrm{~Hz}$ & $10.3 \pm 5.3$ & $41.3 \pm 28.3$ & $0.0004^{*}$ \\
\hline $1024 \mathrm{~Hz}$ & $12.3 \pm 5.3$ & $43.1 \pm 30.4$ & $0.0003^{*}$ \\
\hline $2048 \mathrm{~Hz}$ & $9.0 \pm 7.5$ & $37.5 \pm 31.8$ & $0.0003^{*}$ \\
\hline $3000 \mathrm{~Hz}$ & $6.75 \pm 7.8$ & $34.4 \pm 28.6$ & $0.0003^{*}$ \\
\hline $4096 \mathrm{~Hz}$ & $8.3 \pm 7.3$ & $39.4 \pm 29.9$ & $0.0003^{*}$ \\
\hline $6000 \mathrm{~Hz}$ & $10.3 \pm 6.2$ & $47.2 \pm 29.9$ & $0.0003^{*}$ \\
\hline $8196 \mathrm{~Hz}$ & $9.5 \pm 6.9$ & $44.6 \pm 31.8$ & $0.0001 *$ \\
\hline Pure-tone average $\mathrm{e}^{\mathrm{b}}$ & $10.2 \pm 5.3$ & $36.5 \pm 25.6$ & $0.0010^{*}$ \\
\hline Speech discrimination (\%) & $100 \pm 0.0$ & $89.3 \pm 27.2$ & 0.3472 \\
\hline
\end{tabular}

a Mean \pm standard deviation. ${ }^{b}$ Pure-tone average was calculated as the average of hearing sensitivity at 512, 1024, 2048 and $4096 \mathrm{~Hz}$. ${ }^{*}$ Statistically significant $p$-values ( $\left.\leq \leq 0.05\right)$. Yrs: years, dB: decibel.

\section{Discussion}

While OI is a rare disease, patients suffering from OI will be seen by various medical specialists, it is therefore important for clinicians to know the clinical phenotypes. It has been described that patients with OI can develop HL. However, no prior studies have evaluated the presence of $\mathrm{HL}$ in Chilean patients. We found an overall frequency of $\mathrm{HL}$ of $30 \%$. It is believed that HL begins in early adulthood and progresses with time. Kuurila et al describe a mean age of onset of 29 years, and our cohort had a mean age of 22 years ${ }^{13}$. Therefore, it is expected that more patients will develop HL after this study is completed. It is also believed that there may be some similarities with otosclerosis, known to be more frequent in female patients ${ }^{14,15}$. We did not observe a difference for gender. We speculate that $\mathrm{HL}$ in OI is unrelated to gender ${ }^{5,13}$.

Children with OI can also develop HL, but it is uncommon, and when present, tends to be conductive. We describe only on pediatric patient with SNHL. Of importance in this group is the potential of treatment to decrease the incidence or severity of HL. It has been suggested that bisphosphonates, by inhibiting bone resorption, could delay the progression of HL by improving middle and inner ear ossification ${ }^{5}$. All patients with OI should be monitored for HL, and should include tympanometry with acoustic stapedial reflex, and pure-tone audiometry ${ }^{15-17}$. It has been suggested to begin monitoring around the age of 10 years, and follow-up every three years, depending on the case ${ }^{13}$. It is important to remember that patients can have a normal audiogram but an absent acoustic stapedial reflex, this could be an early sign of $\mathrm{CHL}^{14}$. The stapedial reflex consists in the middle ear muscles stiffening the ossicular chain when presented with a high-intensity sound stimulus. It has been shown that for diseases with stapes footplate fixation, such as OI, the reflex may be absent before hearing loss is observed ${ }^{16,18}$. Once HL is detected treatment includes hearing aids and, is some cases, surgery (stapedotomy) ${ }^{2,5}$. A multidisciplinary approach is ideal for the management of these patients.

This study has some limitations. Because of the small sample size, we could not determine the prevalence of HL in OI. Hence, we describe our results as observed frequencies. Also, since HL in OI increases with age and many of our patients evaluated were around or younger that 18 years- 
old, our results could have underestimated the observed frequency of HL.

\section{Conclusion}

Patients with OI can develop conductive, sensorineural or mixed hearing loss which progresses with time. It is rarely seen in pediatric patients; however, monitoring for hearing loss should began at this stage. All patients with OI should be monitored for hearing loss. While patients may not develop hearing loss initially, the acoustic stapedial reflex can be absent as an early sign of a future conductive hearing loss.

Acknowledgements: We wish to thank the FOICH (Fundación de Osteogénesis Imperfecta Chile) for their participation in distributing information relating to this study to their members, and Dr. Loreto Reyes, pediatric endocrinologist, for providing information relating to her patients included in this study.

\section{References}

1. Marini JC, Forlino A, Bächinger HP, Bishop NJ, Byers $\mathrm{PH}$, De Paepe A, et al. Osteogenesis imperfecta. Nat Rev Dis Primers 2017; 3: 17052.

2. Rossi V, Lee B, Marom R, Osteogenesis imperfecta: advancements in genetics and treatment. Curr Opin Pediatr 2019; 31 (6): 708-15.

3. Mortier GR, Cohn DH, Cormier-Daire V, Hall C, Krakow D, Mundlos S, et al. Nosology and classification of genetic skeletal disorders: 2019 revision. Am J Med Genet A 2019; 179 (12): 2393-419.

4. Shi J, Ren M, Jia J, Tang M, Guo Y, Ni X, et al. Genotype-Phenotype Association Analysis Reveals New Pathogenic Factors for Osteogenesis Imperfecta Disease. Front Pharmacol 2019; 10: 1200.

5. Carré F, Achard S, Rouillon I, Parodi M, Loundon N. Hearing impairment and osteogenesis imperfecta: Literature review. Eur Ann Otorhinolaryngol Head Neck Dis 2019; 136 (5): 379-83.

6. Santos F, McCall AA, Chien W, Merchant S. Otopathology in Osteogenesis Imperfecta. Otol Neurotol 2012; 33
(9): 1562-6.

7. Swinnen FK, Casselman JW, De Leenheer EM, Cremers $\mathrm{CW}$, Dhooge IJ. Temporal bone imaging in osteogenesis imperfecta patients with hearing loss. Laryngoscope 2013; 123 (8): 1988-95.

8. Alkadhi H, Rissmann D, Kollias SS. Osteogenesis imperfecta of the temporal bone: CT and MR imaging in Van der Hoeve-de Kleyn syndrome. AJNR Am J Neuroradiol 2004; 25 (6): 1106-9.

9. Shea JJ, Postma DS. Findings and long-term surgical results in the hearing loss of osteogenesis imperfecta. Arch Otolaryngol 1982; 108 (8): 467-70.

10. Machol K, Hadley TD, Schmidt J, Cuthbertson D, Traboulsi H, Silva RC. Hearing loss in individuals with osteogenesis imperfecta in North America: Results from a multicenter study. Am J Med Genet A 2020; 182 (4): 697-704.

11. da Costa Otavio AC, Teixeira AR, Félix TM, Rosito LPS, da Costa SS. Osteogenesis imperfecta and hearing loss: an analysis of patients attended at a benchmark treatment center in southern Brazil. Eur Arch Otorhinolaryngol 2020; 227 (4): 1005-12.

12. Cammarata-Scalisi F, Ramos-Urrea C, Da Silva G. Osteogenesis imperfect: clinical and epidemiological findings in a series of pediatric patients. Bol Med Hosp Infant Mex 2019; 76 (6): 259-64.

13. Kuurila K, Kaitila I, Johansson R, Grénman R. Hearing loss in Finnish adults with osteogenesis imperfecta: a nationwide survey. Ann Otol Rhinol Laryngol 2002; 11 (10): 939-46.

14. Swinnen FK, Dhooge IJ, Coucke PJ, D’Eufemia P, Zardo F, Garretsen T, et al. Audiologic phenotype of osteogenesis imperfecta: use in clinical differentiation. Otol Neurotol 2012; 33 (2): 115-22.

15. Hald JD, Folkestad L, Swan CZ, Wanscher J, Schmidt M, Gjørup H, et al. Osteogenesis imperfecta and the teeth, eyes, and ears-a study of non-skeletal phenotypes in adults. Osteoporos Int 2018; 29 (12): 2781-9.

16. Martens S, Dhooge JJM, Swinnen FKR. Longitudinal analysis of the audiological phenotype in osteogenesis imperfecta: a follow-up study. J Laryngol Otol 2018; 132 (8): 703-10.

17. Pillion J, Shapiro J. Audiological findings in osteogenesis imperfecta. J Am Acad Audiol 2008; 19 (8): 595-601.

18. Royer M, Stott C, Lara C, Franulic L. Hearing compromise in imperfect osteogenesis. Rev Otorrinolaringol Cir Cabeza Cuello 2006; 66: 243-6. 